\title{
An Investigation Into A Peer Module Mentoring Programme In Economic And Management Sciences
}

Ronel Du Preez, Stellenbosch University, South Africa

Leon P. Steenkamp, Stellenbosch University, South Africa

Roelof S. Baard, Stellenbosch University, South Africa

\begin{abstract}
All South African universities face the challenges of student success and retention - a challenge compounded by under-prepared students from diverse backgrounds. This article explores peer module mentoring as a possible approach to facilitate student success in Economic and Management Sciences. An ex post facto quantitative research methodology, with a web-based questionnaire, was implemented. Perspectives of both mentors and mentees who participated in the faculty module mentoring programme during 2012 were investigated regarding their motivation for participation and evaluation of the programme.
\end{abstract}

The module mentoring programme was experienced as being beneficial by both the mentors and mentees. Altruistic, cognitive, social, personal growth and financial benefits were derived from the programme. The findings provide a strong argument in favour of the expanding and continuation of module mentoring programmes in the Faculty of Economic and Management Sciences. The findings are not generalisable beyond the scope of the particular faculty and institution, but provide input and guidance for decision-making related to student support initiatives. The continuance of the module mentoring programme entails investments in terms of both money and time. This article considers the benefits derived from these investments in a faculty-wide module mentoring programme at a South African university.

Keywords: Mentoring Programme; Student Success; Student Support; Module Mentoring; Economic and Management Sciences

\section{INTRODUCTION}

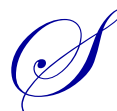

outh African universities are at a crossroad. The higher education sector (both local and international) is faced with numerous challenges, including the broadening of access to university, declining throughput and retention rates, together with the overarching goal of increasing student success in the broadest sense. Institutions experience the financial constraints that go with reduced student numbers, under-prepared students, competition for students, and greater reliance by disadvantaged students on bursaries and loan schemes.

The National Development Plan 2030 (Republic of South Africa 2012, p. 275) envisages the widening of access into the higher education system with an increased participation to $30 \%$. Universities have to contribute to social justice and the cultivation of a welcoming culture for all who wish to enter higher education. Regrettably, this noble goal could include a dark side - students that are under-prepared for success in higher education, large classes with limited contact hours, students without role clarity as to what it means to be a successful student, limited contact with the lecturer, lack of facilities and in-class language and learning barriers stemming from diverse cultural and language backgrounds. The increase in student diversity (including students with disabilities) leads to diverse needs and may require additional support (Adams \& Hayes, 2011; Trotter \& Roberts, 2006). Universities have to navigate these challenges. One approach is student support through mentoring, tutoring and co-curricular 
programmes with the ultimate aim of student success. Student success has been defined in terms of "... not only whether students have earned a degree, but also whether graduates are in fact achieving the level of preparation - in terms of knowledge, capabilities, and personal qualities - that will enable them to both thrive and contribute in a fast-changing economy and in turbulent, highly demanding global, societal and often personal contexts" (Kuh, 2008, p. 2).

Student success, especially in the first year, has received increasing attention in many countries, including South Africa (Steenkamp, Baard \& Frick, 2009; Leibowitz, Van der Merwe \& Van Schalkwyk, 2009). The transition from school to higher education is a potentially difficult process for many students (Beltman \& Schaeben, 2012; McChlery \& Wilkie, 2009; Leibowitz, Van der Merwe \& Van Schalkwyk, 2009). Public consciousness of student success is on the rise as admission to higher education, the cost of higher education and attrition rates receive renewed attention with the publication of the National Development Plan (Republic of South Africa, 2012) and the annual Grade 12 National Senior Certificate examination results. Universities have increasingly implemented student support measures in an effort to aid student success and curb drop-outs (McChlery \& Wilkie, 2009; Van Deventer, 2005). Such support measures are increasingly advocated as a foundational prerequisite for undergraduate success (McChlery \& Wilkie, 2009), which should be available to all students (Adams \& Hayes, 2011; Blythman \& Orr, 2003) in the traditional face-to-face and more recent online formats (Leidenfrost, Strassnig, Schabmann, Spiel \& Carbon, 2011).

Student support mechanisms in Economic and Management Sciences modules have been investigated by authors such as Baard, Steenkamp, Frick and Kidd (2010), Du Plessis, Müller and Prinsloo (2005), Müller, Prinsloo and Du Plessis (2007), Rowlands (1988), Steenkamp, Baard and Frick (2012), De Jager and Bitzer (2013), and Van Rensburg, Penn and Haiden (1998). Steenkamp et al. (2009) considered students' perceptions of factors influencing their success in first year Financial Accounting. They found, inter alia, that students consider the availability of tutors to be beneficial to their studies and that peer tutoring contributed to their academic success.

Fox, Stevenson, Connelly, Duff and Dunlop (2010) propose that over and above the traditional methods of student support - such as tutoring - increased interest is shown for mentoring and peer mentoring as a studentcentred intervention that helps participants to engage in deep learning (Hayes, King \& Richardson, 1997). However, all support efforts come at a cost and, in the study on which this article is based, the module mentoring programme ran parallel to a conventional tutor programme. This article reports on the perspectives of both mentors and mentees who participated in a faculty-wide module mentorship programme at a leading South African university.

\section{LITERATURE REVIEW}

Student support programmes that are based on the theoretical principles of the social integration theory of Tinto (1975) and the social support theory of Pearson (1990) come in many formats, of which supplemental instruction by means of peer mentoring and peer tutoring is gaining support. However, the lack of clarity as to the constructs involved is compounded by the loose manner in which researchers clarify peer-assisted learning, peer tutoring, tutoring, peer mentoring, mentoring and informal tutoring - all of which are used as synonyms (Colvin \& Ashman, 2010, Clark, Andrews \& Gorman, 2012/2013).

One way of differentiating mentorship from peer mentorship relates to the nature of the relationship and the hierarchy involved. Langhout, Rhodes and Osborne (2004) propose four styles of mentoring related to the nature of support, structure and activity in the mentoring relationship; namely, 1) moderate mentors (conditional support and moderate levels of structure and activities), 2) unconditionally supportive mentors (highest level of support with moderate levels of structure and activity), 3) active mentors (highest level of activity combined with the lowest degree of structure), and 4) low-key mentors (highest support and lowest activity). Of these, the moderate mentoring style leveraged the most benefits for mentees. In adding to the work of Langhout et al. (2004), Leidenfrost et al. (2011) identified three peer mentoring styles based on eight indicators related to mentoring functions, quality, motivation and online mentoring activities. The three styles were motivating master mentoring, informatory standard mentoring and negative minimalist mentoring. The motivating master mentor performed well academically, was committed to mentoring sessions, and provided informational and motivational mentoring while avoiding negative mentoring. As expected, this style of mentoring proved to have the biggest impact on underperforming students. 
Peer mentoring within the academic context (module mentoring) is a process whereby reciprocity and equal status abides and both the mentor and the mentee exchange knowledge, ideas, support and interest to the benefit of both parties. Colvin and Ashman (2010) mention that peer tutoring typically involves a more experienced student helping another student with academic work to increase academic performance. However, the peer module mentor's focus is not limited to providing academic support (as in the case of a tutor) but also includes advice, emotional support and efforts to foster personal growth. The result is that both the mentee and the mentor benefit from the psychological contract that guides the relationship between them. This contrasts with traditional mentoring where the mentee is usually much less experienced and knowledgeable and the mentor is of a higher status than the mentee (Beltman \& Schaeben, 2012; Clark et al. 2012/2013; Leidenfrost et al., 2011).

Peer mentoring programmes also differ from peer tutor programmes, since in the former the delineation of the relationship is more hierarchal and academic in nature (often with prescribed curricula) with limited sociopsychological support. Roscoe and Chi (2007, p. 534) define peer tutoring as "the recruitment of one student to provide one-on-one instruction for another student, accompanied by explicit assignment of participants to 'tutor' and 'tutee' roles". The tutee tends to be passive while the tutor is the active, knowledgeable participant (Jacques, 1990). Most higher education institutions support formal tutor programmes within modules and degree programmes as part of the academic offering. Tutoring takes place within formal class time (usually during tutor or practical classes) and the lecturer plays an active role in the development, delivery and assessment of tutor sessions and work done during the sessions. The lecturer briefs tutors on the content of the tutor class (prior to the class) and tutors assist students who have difficulty in mastering the academic work during class. It is important that student support initiatives differentiate between tutoring and mentoring programmes, as they are essentially different. This task can be difficult, as many support programmes share common elements. However, the nature, scope, valence, orientation and goals of these elements are the differentiating variables.

For the purposes of the research reported in this article, the following elements defined the Faculty of Economic and Management Sciences (EMS) module mentoring programme at Stellenbosch University:

- $\quad$ Students assist other students with module-specific academic work to increase academic performance.

- $\quad$ Support is provided to encourage personal growth and development.

- $\quad$ Small-group meetings are voluntary, informal and outside of formal class time and run at least once a week for the duration of the module.

- Mentors must adhere to a minimum academic achievement in the particular module in which they mentor.

- $\quad$ Mentors receive monetary incentives (however limited).

- $\quad$ Lecturers give no or very little direct input toward the sessions.

Peer mentoring programmes have gained significant support stemming mostly from the beneficial outcomes for all the stakeholders, including the university, the lecturer, the mentee and the mentor. Benefits for the university are numerous and include a cost-effective technique to improve academic performance (Dioso-Henson, 2012), an increase in students' engagement in student activities offered by the university as a form of student volunteering (Clark et al., 2012/2013), an increase in retention and a decrease in attrition (Fox \& Stevenson, 2006), and improved satisfaction with the university experience and quality of education received, which could lead to increased commitment to the university (Clark et al., 2012/2013; Higgins, 2004). Some institutions use the mentoring programmes to identify at-risk students (Robinson \& Niemer, 2010) and as an indirect way of retaining subsidy funding from the state as a result of decreased attrition and improved graduate rates (Laing \& Perrin, 2013).

The benefits that the mentor derives from the mentor-mentee interaction are often mistakenly underrated in literature. The reciprocal beneficial relationship between the mentee and the mentor is one of the major advantages of peer mentoring (Beltman \& Schaeben, 2012; Colvin \& Ashman, 2010; Clark et al., 2012/2013; Falchikov, 2001; Fox et al., 2010; Fullick, Smith-Jentsch, Yarbrough \& Scielzo, 2012; Hall \& Jaugietis, 2011; Leidenfrost et al., 2011; Irving, Moore \& Hamilton, 2003). Beltman and Schaeben (2012) name four categories and sub-categories of benefits derived by mentors in an institution-wide peer mentoring programme (altruistic, cognitive, social and personal growth). Their results indicate that the altruistic benefits of enjoyment and satisfaction from helping others were most evident, followed by cognitive benefits (e.g. acquiring new skills such as communication and leadership). In the third place, social benefits, such as interacting with new students, networking and forming friendships, were 
mentioned. Personal growth benefits, including benefits related to self-development such as pride, empathy and responsibility, were the fourth group. Clark et al. (2012/2013) highlight a number of benefits perceived by mentors, such as the opportunity to learn through the process of teaching others, working with other students and discussing matters that one would not ordinarily discuss with members of staff, increased commitment to complete university studies, feeling part of the university and making use of the opportunities the university provides and a positive influence on the approach to learning and the learning experience. These benefits corroborate the findings of Beltman and Schaeben (2012) in that elements of both the altruistic and social benefit categories are affirmed. Jackling and McDowall (2008) report that tutors believed they contributed to students' learning and better understanding of concepts as tutees would rather ask their tutors than their lecturers for assistance (the tutor role is also fulfilled in some ways by the mentor as defined in this study). Hall and Jaugietis (2011) report enhanced leadership, organisational skills and communication of peer mentors.

Mentees are typically the focus of a mentoring programme in that initiatives are primarily developed to enhance mentee success. The benefits derived by mentees include the following:

- the development of deep and strategic learning approaches that focus on understanding and actively engaging the material and being aware of the assessment requirements (Fox et al., 2010)

- $\quad$ increased academic achievement (Fox et al., 2010)

- a sense of belonging to the university and a more pragmatic (rather than emotive) approach to the mentoring programme (Clark et al., 2012/2013)

- $\quad$ the enhancement of a positive transition into university through heightened commitment, positive learning experiences and confidence (Clark et al., 2012/2013)

- $\quad$ positive impacts on the decision to stay at university (retention), social interaction, feeling part of the university, understanding the requirements of the programme and accessing other services offered by the university (Hall \& Jaugietis, 2011)

- $\quad$ the worth of the mentor-mentee relationship in terms of general relational support (Clark et al., 2012/2013; Colvin \& Ashman, 2010)

- $\quad$ reduced stress for first years during the induction and transition into higher education when social support is provided that is consistent with their characteristic disposition (Fullick et al., 2012)

\section{CONTEXT OF THE STUDY}

The South African context is unique because of historical inequalities and persistent social-cultural, economic and educational challenges. Stellenbosch University (South Africa) (SU) formed the narrower context of this study. The university is gaining reputation as a research-led university on various international ranking systems, but at the same time is contending with the challenge of maintaining its unique identity and being more accessible. SU acknowledges the role it has to play in addressing the challenges facing South Africa and specifically higher education. The newly developed Strategy for Teaching and Learning 2013-2017 sets out the institutional vision and strategic priorities for teaching and learning (Stellenbosch University Draft Strategy for Teaching and Learning 2013-2017). The university is committed to enhancing student success and actively promotes effective support and robust academic habits, especially among first-year students. It is unfortunate that "schooling has not been able to transform itself in so far as all young people have the opportunity to matriculate and for students from varied social class backgrounds to develop the kinds of skills, knowledge and attitudes that would make them university-ready" (Stellenbosch University Draft Strategy for Teaching and Learning 2013-2017, p.6). SU has come a long way since the launch of the First Year Academy (an initiative at SU to focus the attention on the challenges facing first-year students) and faculties have actively engaged initiatives to foster student success (not exclusively at first-year level). A variety of support initiatives are offered in the Faculty of Economic and Management Sciences, including hot seats, individual learning programmes, practical classes, tutor and mentoring programmes, summer and winter schools, Blackboard and Moodle support, and early assessment. However, continued efforts are needed to enhance and sustain student success.

The Faculty of Economic and Management Sciences is the largest faculty with a yearly intake of approximately 1,300 first-year students. These students are diverse in terms of race, cultural background, language proficiency, quality of schooling and preparedness for tertiary education. The basic entry requirements stipulate a 
Grade 12 average of $60 \%$, a language proficiency of $50 \%$ in their home language and additional language, as well as Mathematics $60 \%$. Additional (higher) requirements are set for specific programmes. The first-year offering of all the programmes in the faculty are parallel medium (Afrikaans and English groups); thereafter, only the BCom (Management Sciences) programme offers parallel medium in the second and final year.

The module mentoring programme was initiated in 2007 and administered with an electronic management system. This entails that students (mentees) electronically apply to the module mentoring programme for specific modules in which they need support. Senior students (mentors) that adhere to the academic criteria (> 65\%) and undergo the basic four-hour training session on mentoring skills are paired with approximately 10 mentees. They schedule meetings outside of the formal class time (usually once a week) to discuss academic issues and to provide general support. The programme has shown exponential growth with mentorship in 24 modules and 1,815 mentees supported by 141 mentors. The majority of mentees are first-year students; however, provision is also made for second- and third-year modules. It is further evident that not only at-risk students participate; many students use the module mentoring programme since it offers the opportunity to internalise knowledge and engage in deep learning.

The mentoring programme involves substantial investment in terms of time, effort and money by the institution, mentors and mentees. The EMS faculty firmly believes that all these initiatives contribute to the overall success of students. However, the continued budgetary restraints, growing need for support, higher throughput, pass rate and retention expectations, as well as limited staff and resources all warrant an investigation into students' perspectives of the influence of the EMS mentoring programme on their success. The research-initiating question for this study was therefore, "How do mentees and mentors view the module mentoring programme and do they regard it as contributing to their success as an EMS student at Stellenbosch University?"

\section{METHODOLOGY AND DATA COLLECTION}

Two questionnaires were prepared based on those used by Steenkamp, Baard and Frick (2012). The questionnaires were delivered electronically through the Checkbox.com platform. All mentors and mentees registered with the module mentoring programme for 2012 were invited to complete the questionnaires. The invitations were sent in October 2012, two weeks before commencement of the examinations. At that stage the majority of module mentoring sessions were completed. Students had two weeks to complete the questionnaire and were reminded once to complete it if they had not already done so after one week. Mentors and mentees were requested to complete a questionnaire for every module where they participated in the mentoring programme. If a student therefore attended module mentoring sessions for two different modules, they were requested to complete two questionnaires.

The results of the questionnaires were exported to Excel and all instances where the responses were substantially incomplete, they were removed. The responses to open-ended questions were analysed and grouped according to the principles of thematic analysis (Lapadat, 2010), resulting in themes evident from the responses.

\section{RESULTS AND DISCUSSION}

\section{Mentees}

The response rate for the mentees was $21.8 \%$ (395 responses) out of a total of 1,815 invitations sent. The majority of respondents attended module mentoring sessions for Financial Accounting 188 (18.5\%) and Information Systems $188(13.2 \%)$. (Both are of the largest first year modules in the faculty.) In total, mentees participating in all 24 different modules completed the questionnaire. A variety of modules from different year groups were therefore represented. Table 1 shows the reasons why students chose to participate in the module mentoring programme in response to a closed-ended question. 
Table 1: Reasons Selected by Mentees for Participating in the Module Mentoring Programme

\begin{tabular}{|l|c|}
\hline \multicolumn{1}{|c|}{ Reason For Participation In The Module Mentoring Programme } & Percentage \\
\hline I wanted to improve my marks in this module & $71.1 \%$ \\
\hline I struggled with this module & $60.0 \%$ \\
\hline I try to make use of all available academic support measures & $49.9 \%$ \\
\hline Availability of English mentor & $26.6 \%$ \\
\hline I prefer working in small groups & $24.3 \%$ \\
\hline The mentor group motivated me & $24.1 \%$ \\
\hline I am repeating this module & $9.4 \%$ \\
\hline For the social interaction & $2.3 \%$ \\
\hline My parents told me I must attend & $2.0 \%$ \\
\hline Other & $7.6 \%$ \\
\hline
\end{tabular}

Students were able to select more than one option. The total number of responses therefore adds up to more than $100 \%$.

As might be expected, the main reasons for participation were that students wanted to improve their marks and they struggled with the module. However, nearly 50\% indicated that they made use of all available academic support measures. A quarter of the respondents indicated that the availability of an English mentor played a role in their participation. The modules in the EMS Faculty at Stellenbosch University are predominantly presented in Afrikaans and some modules are presented in Afrikaans only. There are, however, many English-speaking students at the university, and they clearly appreciated the opportunity to receive help in their mother tongue.

Mentees were probed to indicate their perceived goal of the module mentoring programme (Table 2). The two main reasons, grasping difficult concepts and opportunity to practise the work, are arguably aligned with the goals of the faculty for the programme.

Table 2: Goal of the Module Mentoring Programme as Perceived by Mentees Perceived Goal Of Module Mentoring Programme

\begin{tabular}{|l|c|}
\hline \multicolumn{1}{|c|}{ Perceived Goal Of Module Mentoring Programme } & Percentage \\
\hline Help me to grasp difficult concepts & $90.1 \%$ \\
\hline Provide me with an opportunity to practise the work more often & $79.7 \%$ \\
\hline Repeat work done in class & $37.0 \%$ \\
\hline Motivate me & $34.2 \%$ \\
\hline Help me with last minute test/exam preparation & $31.9 \%$ \\
\hline Provide me with notes & $15.2 \%$ \\
\hline Socialise & $1.0 \%$ \\
\hline
\end{tabular}

Students were able to select more than one option. The total number of responses therefore adds up to more than $100 \%$.

Of the respondents, only $15.2 \%$ indicated that the goal was to obtain notes. However, upon further analysis of the data, it is clear that only two students $(0.5 \%)$ indicated that this is the main, or only, reason for their participation. The participants in the study were presented with a number of statements regarding a variety of aspects of the module mentoring programme. They were asked to indicate their agreement on a 4-point Likert-type scale ranging from strongly agree to strongly disagree. The results are presented in Table 3.

The overall conclusion from results shown in Table 3 is that the programme was received positively and it should be continued for the next year. Just more than half of the respondents indicated that the mentor explained concepts better than the lecturer and $46 \%$ would rather attend the mentoring sessions than class. This result is in accordance with Jackling and McDowall's (2008) finding that some students prefer to ask assistance from students rather than lecturers. Possible reasons could include that:

- $\quad$ the mentoring sessions are in smaller groups (compared to large classes)

- the mentor can address specific concerns or unclear concepts to a particular student (which is not the case in a large class)

- $\quad$ the mentor may use language that is more comprehensible by the mentee (the language proficiency and use of jargon by the lecturer makes it difficult for the student to follow easily)

- $\quad$ the mentor presents the session in English which may be the mentee's home language (the lecture might be in Afrikaans due to the language policy) 
Table 3: Mentees' Views Regarding the Module Mentoring Programme ( $\mathrm{N}=395)$

\begin{tabular}{|c|c|c|c|c|c|}
\hline & $\begin{array}{l}\text { Strongly } \\
\text { Agree }\end{array}$ & Agree & Disagree & $\begin{array}{l}\text { Strongly } \\
\text { Disagree }\end{array}$ & $\begin{array}{l}\text { Did Not } \\
\text { Answer }\end{array}$ \\
\hline $\begin{array}{l}\text { The mentoring programme for this module must continue next } \\
\text { year }\end{array}$ & $68 \%$ & $27 \%$ & $3 \%$ & $2 \%$ & $2 \%$ \\
\hline Talks on how to study should be presented more regularly & $35 \%$ & $49 \%$ & $13 \%$ & $1 \%$ & $2 \%$ \\
\hline Talks on personal problems should be presented more regularly & $13 \%$ & $34 \%$ & $41 \%$ & $10 \%$ & $2 \%$ \\
\hline $\begin{array}{l}\text { Only students who achieve less than } 50 \% \text { should be on the } \\
\text { programme }\end{array}$ & $8 \%$ & $13 \%$ & $43 \%$ & $34 \%$ & $2 \%$ \\
\hline $\begin{array}{l}\text { Students obtaining less than } 60 \% \text { should be on the mentoring } \\
\text { programme }\end{array}$ & $11 \%$ & $42 \%$ & $32 \%$ & $12 \%$ & $3 \%$ \\
\hline $\begin{array}{l}\text { High achievers can also improve by participating in the } \\
\text { programme }\end{array}$ & $37 \%$ & $46 \%$ & $12 \%$ & $2 \%$ & $3 \%$ \\
\hline High achievers should not be on the mentoring programme & $5 \%$ & $15 \%$ & $44 \%$ & $32 \%$ & $3 \%$ \\
\hline Mentors should receive better training & $22 \%$ & $44 \%$ & $29 \%$ & $3 \%$ & $3 \%$ \\
\hline The mentoring programme lived up to my expectations & $25 \%$ & $49 \%$ & $17 \%$ & $7 \%$ & $2 \%$ \\
\hline $\begin{array}{l}\text { I would advise next year's students to take part in the mentoring } \\
\text { programme }\end{array}$ & $47 \%$ & $43 \%$ & $5 \%$ & $3 \%$ & $3 \%$ \\
\hline I wish I had attended more of the mentoring sessions & $21 \%$ & $30 \%$ & $34 \%$ & $13 \%$ & $3 \%$ \\
\hline $\begin{array}{l}\text { My mentor explained the concepts of this module better than the } \\
\text { lecturers }\end{array}$ & $20 \%$ & $34 \%$ & $35 \%$ & $9 \%$ & $2 \%$ \\
\hline I would rather attend mentoring sessions than lectures & $22 \%$ & $24 \%$ & $34 \%$ & $18 \%$ & $2 \%$ \\
\hline I prepared well for my sessions with the mentor & $7 \%$ & $53 \%$ & $35 \%$ & $4 \%$ & $2 \%$ \\
\hline I only attended sessions with the mentor shortly before tests & $3 \%$ & $11 \%$ & $52 \%$ & $31 \%$ & $3 \%$ \\
\hline $\begin{array}{l}\text { I contributed to the success of the other members of the mentor } \\
\text { group }\end{array}$ & $5 \%$ & $41 \%$ & $43 \%$ & $8 \%$ & $4 \%$ \\
\hline $\begin{array}{l}\text { I enjoyed the interaction with the other students in my mentor } \\
\text { group }\end{array}$ & $11 \%$ & $61 \%$ & $20 \%$ & $5 \%$ & $3 \%$ \\
\hline The mentoring sessions were a social event for me & $1 \%$ & $9 \%$ & $52 \%$ & $35 \%$ & $4 \%$ \\
\hline $\begin{array}{l}\text { If there is a mentoring programme for next year's module (if } \\
\text { you continue with this subject), I would probably make use of it } \\
\text { next year }\end{array}$ & $49 \%$ & $37 \%$ & $8 \%$ & $4 \%$ & $2 \%$ \\
\hline
\end{tabular}

However, the module mentoring programme was not intended to replace or replicate regular classes, but rather to aid student's comprehension of difficult academic concepts and problems in an informal and supportive environment (Van der Meer \& Scott, 2009). Students, for the most part, attended the mentoring sessions regularly, not just before tests and examinations, and they would advise the next year's students to make use of the opportunities afforded by the mentoring programme.

Of the respondents, $77 \%$ felt that not only students achieving less than $50 \%$ should be allowed to participate in the mentoring programme, and $83 \%$ indicated that high achievers can also improve their marks by participating. Approximately 50\% of respondents indicated that they made use of all available academic support (Table 1), supporting the notion that students do not view the mentoring programme as being only for academically weaker students. This view is further corroborated by the response to a separate question where $20 \%$ of the respondents indicated that they were not underachieving in the subject, even though they were participating in the mentoring programme. Academically strong students can and do make use of the programme and this opportunity should thus be maintained. Irving, Moore and Hamilton (2003) found (albeit in a different setting) that academically strong students can have very positive experiences from being mentored. It is evident that students use the module mentoring programme as one method of enhancing deep learning by engaging with the material (Clark et al., 2012/2013).

Two open-ended questions probed mentees with regard to what mentors did well and less well respectively. The mentees indicated that the work and concepts were explained in an understandable manner and that the mentors were well-organised, properly prepared, patient and always willing to help (which broadly agrees with the findings of Clark et al. (2012) that mentors have a strong supportive role to play in addition to the academic role). Mentees also appreciated test and examination tips and techniques. One student's response summarises the general feedback: 
He carries extensive knowledge of the subject and was willing and able to answer any question immediately. He was motivational, kind and resourceful with the regard to the work and faculty.

There were also notable negative behaviours by some of the mentors which were evident from analysing the open-ended questions. The number of negative aspects was, however, limited compared to the positive. The mentees felt that some of the mentors were not well-prepared and did not have sufficient knowledge of the subject to be effective mentors. Mentees would also have liked more sessions and notes, as well as better communication related to the administration of the mentoring sessions. Five respondents did not feel comfortable about asking questions or actively participating in the sessions. Numerous possible explanations could be cited; for example, the students' inability to articulate the question or feelings of inferiority or low self-esteem due to a lack of knowledge.

The largely positive perception of the mentors and module mentoring programme is supported by the fact that $91 \%$ of mentees rated mentors' performance as average or above average (56\% of the respondents rated their mentor's performance as excellent and $35 \%$ as average).

\section{Mentors}

One hundred and forty-one invitations were sent to all the mentors in the faculty's module mentoring programme and 86 of these mentors completed the questionnaire, leading to a response rate of $61 \%$.

In response to an open-ended question, mentors indicated a wide variety of reasons for becoming a mentor. The motivations they expressed corroborated the findings of Jackling and McDowall (2008) and Beltman and Schaeben (2012) who indicated four principle categories of motivations; namely, altruistic, cognitive, social and personal growth (in order of dominance). These reasons include purely altruistic (wanting to help other students), cognitive (own academic benefit), social (learning life skills and making a difference), and personal growth (selfconfidence) motivations. Results indicate that a fifth category could be added to the classification; namely, that of financial motivation (remuneration). Students noted the following:

At first for the money, but later I realised that it also helped me with my subject. Just to understand the basics again.

I remember how much the mentor helped me in my first year and wanted to do the same.

Mentors, however, regarded the remuneration insufficient given the time and effort invested in the process of mentoring. Some proposed adding non-monetary rewards if the budget did not allow for an increase in the hourly rate, for example:

If I didn't have an utmost passion for teaching, I actually wouldn't do it again. After consulting some of the people studying with me who had been mentors before, and asking them why they aren't willing to do it this year, their one and only reason was that the money isn't worth the time you give up.

The experiences of the mentors of the mentoring programme were generally positive (refer to Table 4). Mentors believe that the programme benefits students and that it should continue. Importantly, the mentors themselves also benefitted from being a mentor through improved self-confidence (similar to the findings of Beltman and Schaeben, 2012, and Hall and Jaugietis, 2011), as well as improved technical knowledge of the subject (which supports the findings of Dioso-Henson, 2012). However, it is clear that the mentors regard the programme in its current format as both an academic support programme and a social and life skill enhancing support mechanism. As in the responses from mentees, the mentors indicated that talks on study techniques, for example, would be welcomed. This is surprising as the university does offer a variety of seminars on generic study techniques and time management. It could well be that the demand is rather for seminars or lectures that are tailored specifically to the modules in question. Similar to the mentees' responses, the mentors felt that the mentoring programme should not be exclusionary and high achievers should be allowed to benefit from it as well. 
Table 4: Mentors' Views Regarding the Module Mentoring Programme ( $N=86)$

\begin{tabular}{|c|c|c|c|c|c|}
\hline & $\begin{array}{l}\text { Strongly } \\
\text { Agree }\end{array}$ & Agree & Disagree & $\begin{array}{l}\text { Strongly } \\
\text { Disagree }\end{array}$ & $\begin{array}{l}\text { Did Not } \\
\text { Answer }\end{array}$ \\
\hline $\begin{array}{l}\text { The mentoring programme for this module } \\
\text { should continue next year }\end{array}$ & $80 \%$ & $16 \%$ & $3 \%$ & $0 \%$ & $0 \%$ \\
\hline $\begin{array}{l}\text { Talks on how to study should be presented more } \\
\text { regularly }\end{array}$ & $31 \%$ & $50 \%$ & $17 \%$ & $1 \%$ & $0 \%$ \\
\hline $\begin{array}{l}\text { Talks on personal problems should be presented } \\
\text { more regularly }\end{array}$ & $7 \%$ & $38 \%$ & $47 \%$ & $8 \%$ & $0 \%$ \\
\hline $\begin{array}{l}\text { Only students who achieve less than } 50 \% \text { should } \\
\text { be on the programme }\end{array}$ & $10 \%$ & $12 \%$ & $44 \%$ & $34 \%$ & $0 \%$ \\
\hline $\begin{array}{l}\text { Students obtaining less than } 60 \% \text { should be on } \\
\text { the mentoring programme. }\end{array}$ & $16 \%$ & $43 \%$ & $29 \%$ & $12 \%$ & $0 \%$ \\
\hline $\begin{array}{l}\text { High achievers can also improve by participating } \\
\text { in the programme }\end{array}$ & $44 \%$ & $37 \%$ & $13 \%$ & $6 \%$ & $0 \%$ \\
\hline $\begin{array}{l}\text { High achievers should not be on the mentoring } \\
\text { programme }\end{array}$ & $8 \%$ & $16 \%$ & $40 \%$ & $36 \%$ & $0 \%$ \\
\hline Being a mentor lived up to my expectations & $23 \%$ & $51 \%$ & $21 \%$ & $2 \%$ & $2 \%$ \\
\hline $\begin{array}{l}\text { I am satisfied with the financial remuneration } \\
\text { received for being a mentor }\end{array}$ & $16 \%$ & $53 \%$ & $20 \%$ & $10 \%$ & $0 \%$ \\
\hline $\begin{array}{l}\text { I learned a lot about this subject by being a } \\
\text { mentor }\end{array}$ & $36 \%$ & $47 \%$ & $16 \%$ & $1 \%$ & $0 \%$ \\
\hline I learned life skills by being a mentor & $30 \%$ & $65 \%$ & $3 \%$ & $1 \%$ & $0 \%$ \\
\hline $\begin{array}{l}\text { I would recommend other students to be a mentor } \\
\text { for this module }\end{array}$ & $36 \%$ & $53 \%$ & $9 \%$ & $0 \%$ & $1 \%$ \\
\hline $\begin{array}{l}\text { The communication of what was expected of me } \\
\text { as mentor was done well }\end{array}$ & $33 \%$ & $49 \%$ & $16 \%$ & $2 \%$ & $0 \%$ \\
\hline $\begin{array}{l}\text { The information received on what was being } \\
\text { done in class helped me to prepare for my } \\
\text { mentoring sessions }\end{array}$ & $31 \%$ & $33 \%$ & $17 \%$ & $17 \%$ & $1 \%$ \\
\hline I prepared well for mentor contact sessions & $47 \%$ & $47 \%$ & $6 \%$ & $1 \%$ & $0 \%$ \\
\hline $\begin{array}{l}\text { I felt I made a difference in the life of at least one } \\
\text { of the students in my group }\end{array}$ & $64 \%$ & $31 \%$ & $5 \%$ & $0 \%$ & $0 \%$ \\
\hline $\begin{array}{l}\text { The academic skills that students in my group } \\
\text { learned are more important than the life skill }\end{array}$ & $14 \%$ & $53 \%$ & $30 \%$ & $2 \%$ & $0 \%$ \\
\hline Students in my group helped each other & $23 \%$ & $57 \%$ & $16 \%$ & $2 \%$ & $1 \%$ \\
\hline $\begin{array}{l}\text { I was able to transfer my love for this subject to } \\
\text { the students in my group }\end{array}$ & $20 \%$ & $59 \%$ & $20 \%$ & $0 \%$ & $1 \%$ \\
\hline Being a mentor built my own self-confidence & $47 \%$ & $48 \%$ & $6 \%$ & $0 \%$ & $0 \%$ \\
\hline
\end{tabular}

Even though some mentors felt that the remuneration should be increased, the vast majority (89\%) indicated that they would still recommend other students to be a mentor. This position resonates with Colvin and Ashman's (2010) finding that remuneration is not a primary concern for mentors. A potential area for enhancement is increased communication between lecturers and mentors as it would aid mentors in their preparation for the mentoring sessions.

In open-ended questions, mentors were asked to judge their strengths and weaknesses as a mentor. They felt they were well-prepared and that they had the ability to share knowledge and information with mentees. They believed that they created a positive and comfortable atmosphere that is conducive to learning. Mentors were particularly satisfied with their ability to provide mentees with general tips and techniques related to academia. From the mentors' responses, it appears that their intention was not necessarily to give tips for mentees to simply pass examinations, but rather to assist them in understanding concepts and to identify what constitutes important topics in the module. An element of conveying good examination technique was evident, but this was not the primary goal, as can be construed from the responses by mentors. One mentor explained it as follows:

Try to teach them to understand the concept and to help them in preparing for the tests; also to show them that it is not that difficult and what to focus on. 
Mentors were realistic about their shortcomings and where they could improve. They indicated that they were not always prepared sufficiently and sometimes struggled with conveying some knowledge or answering questions. They also sometimes felt that their teaching technique was lacking or that they did not create an ideal environment for interaction with their mentees. The information to determine whether the perceptions of mentees of specific mentors matched those of the mentors was not available. It is suggested that future research may be conducted to compare mentees' perceptions of specific mentors with those specific mentors' own perceptions in terms of what they did well and less well. The following two responses are typical and indicative of explanations of the mentors' shortcomings:

I left most of the content of the sessions up to the mentees and what they were struggling with. If they didn't have specific questions, the lessons didn't always flow smoothly.

I think there were times I was unable to communicate my reasoning successfully to the mentees.

From an analysis of a number of open-ended questions, it was evident that mentors experienced a number of frustrations, some of which may be alleviated by interventions on the part of the faculty. By far, the biggest frustration was the poor level of commitment of some mentees, manifesting in poor attendance, not paying attention during the session, or simply not replying or responding to communication from mentors. Lecturers could assist mentors by aiding them in booking venues and providing more detail on work that was covered in class. One mentor summarised the benefits and frustrations of the mentoring programme as follows:

Some students don't take the lessons seriously enough, but we can't just kick them out of the programme. Others really appreciate and benefit from the lessons, so it's definitely worth carrying on!

One of the general frustrations was the different levels of academic achievement in the same group. In spite of this frustration, the mentors indicated (see Table 4) that high achievers should also be allowed to make use of the mentoring programme. Mentors also voiced frustration with mentees expecting too much from the mentoring programme; i.e., that the mentoring sessions are supposed to replace attending lectures. This is clearly not the case and is untenable in the longer term.

In a separate open-ended question, approximately half of the respondents indicated that they could have used more training. They commented that the requested training should focus on teaching techniques as well as the new work that mentors did not cover when they were students.

\section{CONCLUSION}

This article reports on research conducted on the peer module mentoring programme in the Faculty of Economic and Management Sciences at Stellenbosch University in South Africa. From the literature, it was to be expected that there are benefits to be derived from implementing a mentoring programme. However, due to large investments in time (by university, mentors and mentees) and money (by the university), as well as the context of student support at the faculty, it is imperative to determine empirically the perceived outcome of the mentoring programme to ascertain that there are indeed actual benefits.

Two web-based questionnaires were sent to all mentors and mentees that participated in the faculty's module mentoring programme. A response rate of $21.8 \%$ and $61 \%$ among mentees and mentors, respectively, was achieved. This response rate could be regarded as high, given that students are notoriously non-responsive (for example, the vote percentage for the student parliament only reaches approximately 5\%). The inference could be made that the module mentoring programme was viewed as being important enough to warrant feedback.

The majority of the mentees were positive about the mentoring programme and felt that it should be continued for the next year. Mentees would also wish the programme to be available for modules in subsequent years of study (thus expanding the second- and third-year support). This finding supports the stream of research acknowledging that support is not only needed at first-year level, but that students at different academic milestones need different types of support (Portas \& Keup, 2011). 
An important finding is that the module mentoring programme is not only used and supported by underachievers or at-risk students. High achievers participated in the programme as well and the general feeling was that all students should be allowed to participate, irrespective of their academic ability.

Mentors were likewise positive about the programme and were satisfied that there are benefits for mentees. Mentors also benefitted from participating in the programme as mentors, with altruistic and cognitive benefits being most prevalent. Over and above the social and personal growth benefits, mentors also identified the financial remuneration received from the university as an additional benefit.

Mentors experienced frustrations, some of which are typical for anybody acting in a teaching role, such as non-attendance, a lack of interest and non-response to communications. Some frustrations resulted from the nature of the programme (for example, being informal, administered by mentors, not part of the scheduled class day, struggling to find venues or suitable time slots). The university or faculty could assist with minimising some of the frustrations; for example, by providing allocated venues. Mentors should be made aware of the potential frustrations such as non-attendance during training.

The module mentoring programme is clearly beneficial to students. From the responses, it is clear that the mentees displayed positive attitudes towards the programme. Based on the academic merit and the reputational aspect thereof, there is a strong argument for continuing with the programme. It benefits the university and faculty in promoting academic success, increasing throughput and decreasing attrition. It also benefits students as they will have a better chance of success at university (in the broadest sense). Both mentors and mentees engage with learning material to such an extent that it promotes deep learning. Over and above the increased understanding of academic work, the benefits for personal growth and development for mentees and mentors alike are obvious. The benefits of internalised academic knowledge, leadership and communication skills and responsibility will serve their future employers well.

\section{AUTHOR INFORMATION}

Ronel du Preez $(\mathrm{PhD})$ is the Vice-Dean (Teaching) at the Faculty of Economic and Management Sciences and Associate Professor at the Department of Industrial Psychology at Stellenbosch University. Her teaching and research expertise falls primarily within the field of Consumer Behaviour. Ronel received recognition for excellence in teaching and she is an NRF graded researcher. She acts as subject-editor for the South African Journal of Industrial Psychology and has published numerous peer-reviewed articles and presented several papers at international conferences in the field of consumer behaviour. With her recent appointment as Vice-Dean, her research interest has shifted toward students as "consumers" of higher education with a focus on fostering student

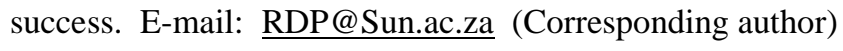

Leon P. Steenkamp (CA(SA), MAcc) is a senior lecturer in Department of Accounting at Stellenbosch University and is primarily involved in teaching Information Systems to students studying toward becoming chartered accountants and Risk Management to B Com Honours. His research interests include accounting education, transdisciplinary research, accounting information systems and matters related to the accounting profession as a whole. He has published a number of peer-reviewed articles and presented at conferences in these research areas. E-mail: Lsteenkamp@sun.ac.za

Roelof S. Baard (MBA, CIMA passed finalist) has been a lecturer in Department of Accounting at Stellenbosch University since 2003 and is involved in teaching Financial Accounting to first-year students studying toward a BComm degree as well as Advanced Financial Accounting to HonsBComm (Management Accounting) students. He has been the recipient of a number of teaching awards, recognizing his contribution to first-year success. Roelof has implemented and is still responsible for a number of support programmes for first-year students. His research interests are accounting education for first-year students and trans-disciplinary research. He is involved in various institutional and departmental research initiatives in these areas. E-mail: Rbaard@sun.ac.za 


\section{REFERENCES}

1. Adams, D. F., \& Hayes, S. G. (2011). Integrating Tutor Training into Faculty Mentorship Programming to Serve Students with Disabilities. Learning Assistance Review, 16(2), 7-21.

2. Baard, R.S., Steenkamp, L.P., Frick, B.L. \& Kidd, M. (2010). Factors influencing success in first-year Accounting at a South African university: the profile of a successful first-year Accounting student. South African Journal of Accounting Research, 24(1):129-147.

3. Beltman, S., \& Schaeben, M. (2012). Institution-wide peer mentoring: Benefits for mentors. The International Journal of the First Year in Higher Education, 3(2), 33-44.

4. Blythman, M. \& Orr, S. (2003). A joined-up policy approach to student support. In M. Peelo \& T. Wareham (Eds.). Failing students in higher education (pp. 44-55). Buckingham: SRHE/Open University Press.

5. $\quad$ Clark, R., Andrews, J. \& Gorman, P. (2012/2013). Tackling Transition: The value of peer mentoring. Widening Participation and Lifelong Learning, 14(1), 57-75.

6. Colvin, J.W. \& Ashman, M. (2010). Roles, risks, and benefits of peer mentoring relationships in higher education. Mentoring \& Tutoring: Partnership in Learning, 18(2), 121-134.

7. De Jager, E. \& Bitzer, E. (2013). First-year students' participation and performance in a financial accounting support group. International Business \& Economics Research Journal, 12(4), 399-414.

8. Dioso-Henson, L. (2012). The effect of Reciprocal Peer Tutoring and non-Reciprocal Peer Tutoring on the performance of students in college physics. Research in Education, 87(1), 34-49.

9. Du Plessis, A., Müller, H. \& Prinsloo, P. (2005).Determining the profile of the successful first-year accounting student. South African Journal of Higher Education, 19(4), 684-698.

10. Falchikov, N. (2001). Learning together: peer tutoring in higher education. New York: Routledge Falmer.

11. Fox, A. \& Stevenson, L. (2006).Exploring the effectiveness of peer mentoring of accounting and finance students in higher education. Accounting Education, 15(2), 189-202.

12. Fox, A., Stevenson, L., Connelly, P., Duff, A., \& Dunlop, A. (2010). Peer-mentoring undergraduate accounting students: The influence on approaches to learning and academic performance. Active learning in higher education, 11(2), 145-156.

13. Fullick, J. M., Smith-Jentsch, K. A., Yarbrough, C. S., \& Scielzo, S. A. (2012). Mentor and Protege Goal Orientations as Predictors of Newcomer Stress. Journal of the Scholarship of Teaching and Learning, 12(1), 59-73.

14. Hall, R., \& Jaugietis, Z. (2011). Developing peer mentoring through evaluation. Innovative Higher Education, 36(1), 41-52.

15. Hays, K, King, E. \& Richardson, J.T.E. (1997). Mature students in higher education: III. Approaches to studying in access students. Studies in Higher Education, 22(1), 19-32.

16. Higgins, B. (2004). Relationship between retention and peer tutoring for at-risk students. The Journal of Nursing Education, 43(7), 319.

17. Irving, S.E., Moore, D.W., \& Hamilton, R.J. (2003). Mentoring for high ability high school students. Education and Training, 45(2), 100-109.

18. Jackling, B. \& McDowall, T. (2008). Peer mentoring in an accounting setting: a case study of mentor skill development. Accounting Education, 17(4), 447-462.

19. Jacques, D. (1990). Being a personal tutor. Oxford: Oxford Polytechnic.

20. Kuh, G.D. (2008). High-Impact Practices: What they Are, Who has Access to them, and Why they Matter. Washington DC: Association of American Colleges and Universities.

21. Laing, G.K. \& Perrin, R.W. (2013). A mentor assisted program of study (maps) for spreadsheet applications in first year accounting: a descriptive study. Asean Journal of Teaching and Learning in Higher Education, 5(1), 50-56.

22. Langhout, R.D., Rhodes, J.E. \& Osborne, L.N. (2004). An exploratory study of youth mentoring in an urban context: Adolescents' perceptions of relationship styles. Journal of Youth and Adolescence, 33(4), 293-306.

23. Lapadat, J. (2010). Thematic Analysis. In Mills, A.J., Durepos, G. \& Wiebe E. (Eds.), Encyclopedia of Case Study Research. (pp. 926-928). Thousand Oaks, CA: SAGE Publications, Inc.

24. Leibowitz, B., Van der Merwe, A. \& Van Schalkwyk, S. (eds). (2009). Focusing on first-year success: perspectives emerging from South Africa and beyond. Stellenbosch, South Africa: Sun Media. 
25. Leidenfrost, B., Strassnig, B., Schabmann, A., Spiel, C. \& Carbon, C.C. (2011). Peer mentoring styles and their contribution to academic success among mentees: A person-oriented study in higher education.

Mentoring \& Tutoring: Partnership in Learning, 19(3), 347-364.

26. McChlery, S. \&Wilkie, J. (2009).Pastoral support to undergraduates in higher education. International Journal of Management Education, 8(1), 23-35.

27. Müller, H., Prinsloo, P. \& Du Plessis, A. (2007).Validating the profile of a successful first-year accounting student. Meditari Accountancy Research, 15(1), 19-33.

28. Pearson, R.E. (1990). Counselling and social support: Perspectives and Practice. Newbury Park, CA: Sage Publications.

29. Portas, M. \&Keup, J. (2011) Transitions beyond the first year: Implications for curriculum design, student support and success. Paper presented at the 25th International Conference on the First Year Experience, Vancouver, British Columbia, Canada.

30. Republic of South Africa. (2012). National Development Plan. Our Future - Make it work. Retrieved May, 21, 2013, from http://www.info.gov.za/view/DynamicAction?pageid=623\&myID=348761

31. Robinson, E. \& Niemer, L. (2010). A peer mentor tutor program for academic success in nursing. Nursing education perspectives, 31(5), 286-289.

32. Roscoe, R. D. \& Chi, M. T. (2007). Understanding tutor learning: Knowledge-building and knowledgetelling in peer tutors' explanations and questions. Review of Educational Research, 77(4), 534-574.

33. Rowlands, J.E. (1988). The effect of secondary school accounting study on school performance in the first year university financial accounting course. De Ratione, 2(2), 17-21.

34. Steenkamp, L.P., Baard, R.S. \& Frick, B.L. (2009). Factors influencing success in first-year accounting at a South African university: a comparison between lecturers' assumptions and students' perceptions. South African Journal of Accounting Research, 23(1), 113-140.

35. Steenkamp, L.P., Baard, R.S. \& Frick, B.L. (2012). A holistic investigation into a tutor programme in firstyear Financial Accounting. Meditari Accountancy Research, 20(1), 68-87.

36. Stellenbosch University.(2003). Stellenbosch University Teaching Management Plan 2003-2007. Retrieved September, 14, 2010 from http://sun025.sun.ac.za/portal/page/portal/Administrative_Divisions/INB/Home/Documentation/Document ation_SU_policy/teachingmanagementplan.pdf

37. Stellenbosch University. (2013). Draft Strategy for Teaching and Learning 2013 - 2017. Unpublished document. Stellenbosch University, Stellenbosch.

38. Tinto, V. (1993). Leaving college: rethinking the causes and cures of student attrition (2 ${ }^{\text {nd }}$ ed.). Chicago: University of Chicago Press.

39. Trotter, E. \& Roberts, C.A. (2006). Enhancing the early student experience. Higher Education Research and Development, 25, 371-386.

40. Van der Meer, J., \& Scott, C. (2009). Students' experiences and perceptions of peer assisted study sessions: towards ongoing improvement. Journal of Peer Learning, 2(1), 3-22.

41. Van Deventer, I. (2005). Die ontwikkeling van 'n tutorprogram: 'n dosentehandleiding. Internal document: Stellenbosch University. Retrieved February, 23, 2010 from

http://sun025.sun.ac.za/portal/page/portal/Administrative_Divisions/SOL/Sol\%20Tuisblad/SOLDienste/Tut orprogram/Dosentehandleiding Tutorprogram.pdf

42. Van Rensburg, P., Penn, G. \& Haiden, M. (1998).A note on the effect of secondary school accounting study on university accounting performance. South African Journal of Accounting Research, 12(1), 93-98. 


\section{NOTES}

